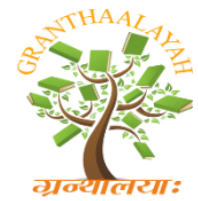
\author{
GRANTHAALAYAH \\ A knowledge Repository
}

INTERNATIONAL JOURNAL OF RESEARCH -

Science

\title{
AN ERA OF CHANGING THE ENVIRONMENTAL CONDITION BY GREEN SUPPLY CHAIN MANAGEMENT
}

\author{
Pratiksha Singh *1, Naman Singh ${ }^{2}$, Gaurav Kumar ${ }^{3}$, Virendra Kumar ${ }^{4}$, Swati Dwivedi ${ }^{5}$, \\ Shubhangi Dixit ${ }^{6}$, Srinath Pandey ${ }^{7}$, Ved Kumar Mishra ${ }^{8}$, Prashant Ankur Jain ${ }^{9}$ \\ *1, 3 Department of Mechanical Engineering, MNIT Jaipur, Rajasthan, India \\ ${ }^{2}$ Department of Electronics and Instrumentation, Krishna Institute of Engineering and \\ Technology, Ghaziabad, U.P., India \\ ${ }^{4}$ Department of Mechanical Engineering, Naraina Vidya Peeth Engineering and Management \\ Institute, Panki, Kanpur, U.P., India \\ 5, 6, 7, 8 Department of Biotechnology, Naraina Vidya Peeth Engineering and Management \\ Institute, Panki, Kanpur, U.P., India \\ ${ }^{9}$ Department of Computational Biology and Bioinformatics, Jacob School of Biotechnology and \\ Bioengineering, SHIATS-Allahabad, U.P., India
}

DOI: https://doi.org/10.29121/granthaalayah.v5.i1.2017.1730

\begin{abstract}
Green supply chain management is defined as the process of using environmentally friendly inputs and transforming these inputs into outputs that can be reclaimed and re-used at the end of their life cycle thus, creating a sustainable supply chain. GSCM is one of the recent innovations for the enhancement of capabilities of Supply Chain Management. The purpose of this paper is to carry out a theoretical review of Green supply chain management (GSCM). The assessment involved 144 research articles published in 48 selected journals between 1998 and 2013. The methodology of empirical research involved selection and classification of 144 research articles in GSCM. A systematic classification and a critical analysis is carried out so as to identify research gaps in content of GSCM, as well as to recommend directions for future research. It is concluded from the analysis of the results that research in GSCM is increasing at a faster rate than ever; with theory building more in focus than verification. Furthermore, a new taxonomy was proposed on the basis of content and research methodology utilised. Based on this taxonomy, significant trends were observed and some unique inferences were drawn, apart from identifying the directions for future research. There have been a couple of literature reviews in GSCM but none of them focused exclusively on research methodology in GSCM. Also the sample size with respect to the number of papers (144 papers), as well as number of journals (48 journals), is larger than ever considered for literature review in GSCM. The papers spans a longer time period of 16 years (1998-2013).
\end{abstract}

Keywords: Green Supply Chain Management; Empirical Research; Literature Review. 
Cite This Article: Pratiksha Singh, Naman Singh, Gaurav Kumar, Virendra Kumar, Swati Dwivedi, Shubhangi Dixit, Srinath Pandey, Ved Kumar Mishra, and Prashant Ankur Jain. (2017). "AN ERA OF CHANGING THE ENVIRONMENTAL CONDITION BY GREEN SUPPLY CHAIN MANAGEMENT.” International Journal of Research - Granthaalayah, 5(1), 144-162. https://doi.org/10.29121/granthaalayah.v5.i1.2017.1730.

\section{Introduction}

The cross-disciplinary field of green supply chain management (GSCM) has been growing in recent years with an interest from both academia and industry. The growing importance of GSCM is driven mainly by the escalating deterioration of the environment, e.g. diminishing raw material resources, overflowing waste sites and increasing levels of pollution. However, it is not just about being environment friendly; it is about good business sense and higher profits. (Srivastava S.K. 2007) Hence, the scope of GSCM ranges from reactive monitoring of the general environment management programs to more proactive practices implemented through various Rs (Reduce, Re-use, Rework, Refurbish, Reclaim, Recycle, Remanufacture, Reverse logistics, etc.).

\section{Green Supply-Chain Management Defined}

Green supply-chain management has its roots in both environment management and supply chain management literature. Adding the 'green' component to supply-chain management involves addressing the influence and relationships between supply-chain management and the natural environment. Similar to the concept of supply-chain management, the boundary of GSCM is dependent on the goal of the investigator.

The definition and scope of GSCM in the literature has ranged from green purchasing to integrated green supply chains flowing from supplier to manufacturer to customer (Zhu and Sarkis 2004). For the purpose of this paper, GSCM is defined as 'integrating environmental thinking into supply-chain management, including product design, material sourcing and selection, manufacturing processes, delivery of the final product to the consumers as well as endof-life management of the product after its useful life'. We specifically focus on RL and mathematical modeling aspects in order to facilitate further study and research.

The objective of the paper is to provide a critical analysis of empirical research content in GSCM. This paper can also serve as a useful reference for researchers in GSCM or other operations fields to advance organizational theory building and applications. The paper is organised as follows: Section 2 discusses literature reviews in GSCM and section 3 deals with methodology chosen for carrying out a structured review on GSCM. The proposed taxonomy and its associated structural attributes are explained in detail in this section. Section 4 provides a discussion on the results based on such taxonomy, while Section 5 ends with conclusions.

The literature in GSCM has been growing as organizations and researchers begin to realize that the management of environmental programs and operations do not end at the boundaries of the organization. Overall, research in corporate environmental management and its operations relationships have been growing in recent years with a number of papers outlining these 
relationships (Sarkis, 2001), including the identification of a need to investigate GSCM. GSCM's definition has ranged from green purchasing to integrated supply chains flowing from supplier, to manufacturer, to customer and reverse logistics, which is "closing the loop" as defined by supply chain management literature (Zhu and Sarkis, 2004). Similar to the concept of supply chain management, the boundary of GSCM is dependent on the goal of the investigator. The research in GSCM addresses a variety of issues ranging from organizational research and practice in GSCM (Hall, 2001) to prescriptive models for evaluation of GSCM practices and technology (Sarkis, 2003).

\section{Methodology}

This section of paper elaborates the methodology adopted for the purpose of providing a comprehensive and critical literature review of GSCM. The issues of time horizon of review, journal selection, article selection, article classification and analysis of articles will be discussed under literature review methodology.

Step 1: The assessment period of articles is between 1998 and 2013, a 16-year time horizon. The year 1998 is considered as the starting point of data collection because term "Green Supply Chain Management" first appeared in 1998 (McIntyre et al. 1998).

Step 2: The articles were collected from five major management science publishers viz. Science Direct, Emerald Online, Sage, T\&F and JSTOR as majority of well-referred journals of industrial management are found in these databases.

Step 3: Exact phrase "supply chain and green" was searched in abstract, title and keyword of all four databases. To reduce the repetition and to enhance the acceptability of the source from where the papers are collected, it was decided to consider only those research papers that are published in peer-reviewed journals.

Table shows the details of articles searched in terms of distribution of articles with respect to each of the search items.

Step 4: All the selected research articles are classified under following eight classes:

Related issues in GSCM: It represents the issue covered in an article. For example implementation, integration of GSCM etc.

- Entity of analysis: It represents the focal entity under analysis in a given article. For example, supplier, manufacturer, distributor, retailer, 3PL, etc. The term "supplier" here means an entity that exists on inbound side of supply chain and supplies raw material or semi-finished product to "manufacturer". While "manufacturer" is final finished product supplier to any one of "distributor", "retailer", "third-party logistics (3PL)", "fourth-party logistic (4PL) provider" or "consumer". All entities including "distributor", "retailer", "3PL" or "4PL" lie on outbound side of supply chain and are involved in distribution of final finished product.

- Level of analysis: This class is adopted from an analytical framework for critical literature review given by Croom et al. (2000). Although Croom et al. (2000) suggested 
only three levels, i.e. dyadic, chain and network,Halldo'rsson and Arlbjørn (2005) have addressed the fourth level, also denoted by "firm".

- Element of exchange: this class is about "what" is exchanged in the supply chain (material assets, financial assets, human resource assets, technological assets, information and knowledge) and "how" relationships between actors are conducted and managed.

- Mode of study: It tells about whether the analysis of any paper is done on empirical basis or on Desk basis.

- Data analysis method: It tells about the tool or method used for analysis,

- Performance measurement: A performance measurement system plays an important role in managing a business as it provides the information necessary for decision making and actions.

- Sample industry: GSCM research is not restricted to any particular industry. It isthus important to find out the range of industries from which data are collected. This classification criterion will thus help in identifying possible sectors of GSCM research as well as highlight sectors that received inadequate attention of researchers.

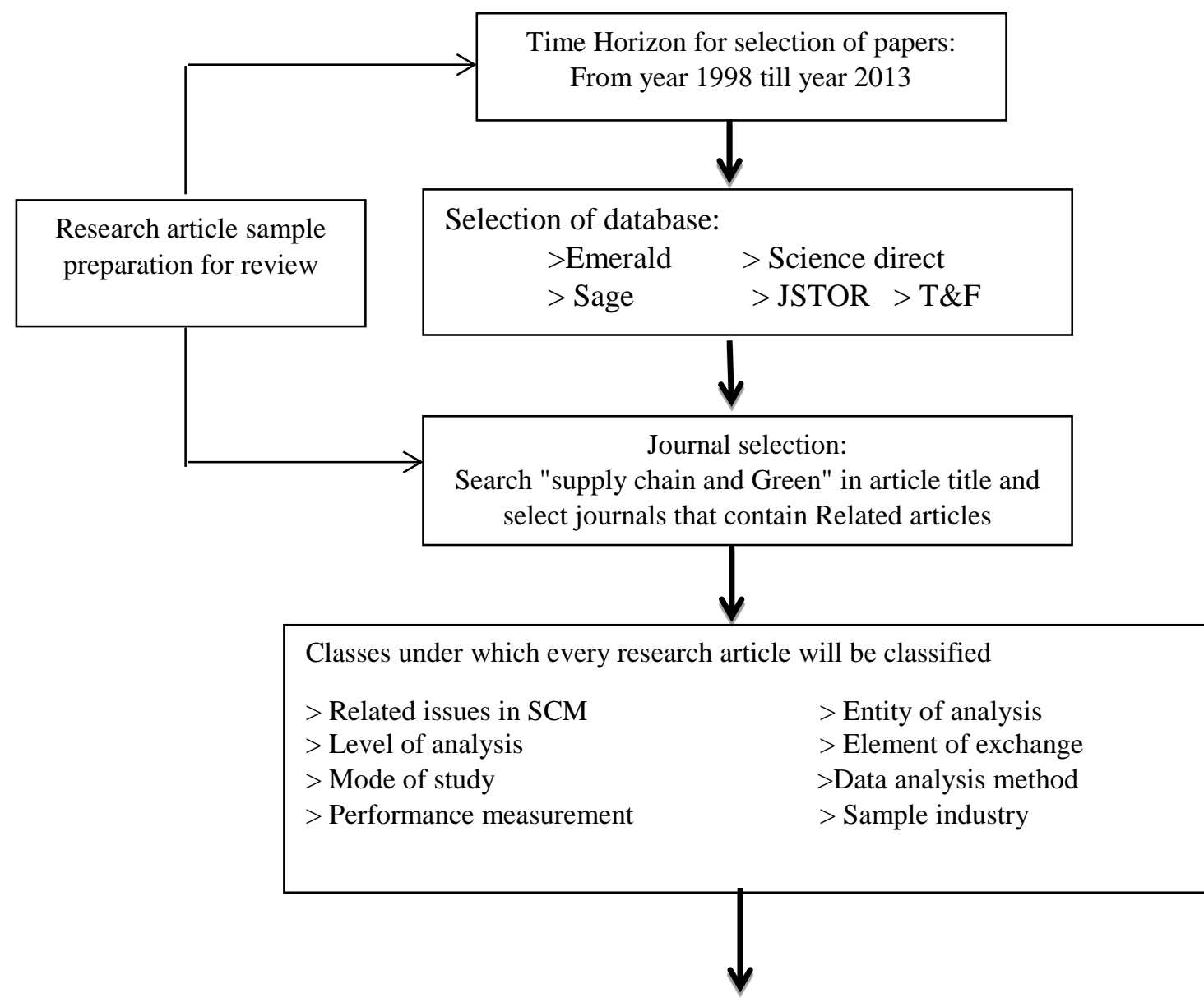

Step 1

Step 2

Research article sample

Classes under which every research article will be classified

$>$ Related issues in SCM $>$ Entity of analysis

Level of analysis

exchange

Data analysis method

Step 3

$>$ Mode of study

$>$ Sample industry 


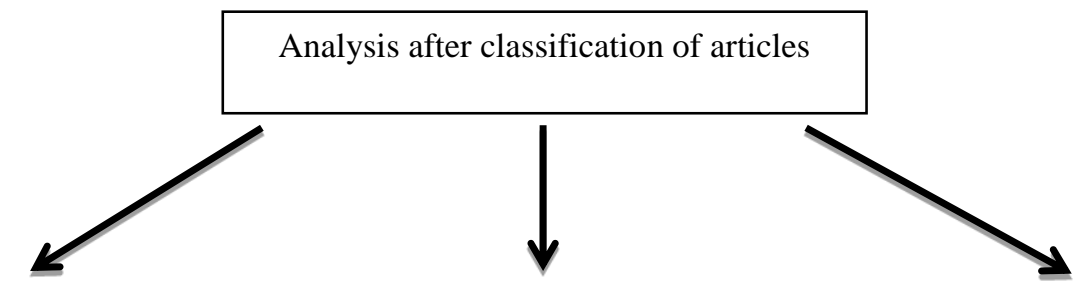

Step 5

Outcome 1: Gaps identified

Outcome 2: Significant findings

Outcome 3: Future directions

Figure 1:

Step 5: In this step, all the efforts are directed towards critically analysing the classified articles so as to identify research gaps in content of SCM in empirical research as well as to present significant findings from the existing literature.

The obtained papers were classified based on the following two major schemes as defined in (Soni and Kodali, 2011; Soni and Kodali, 2012):

a) Content based

b) Research based

These classifications have been described in detail in the following sections.

\section{Content based classification}

The content based classification is carried out by considering the following attributes and the description of the same are presented here.

i. Entity of analysis: A GSC consists of various entities such as the manufacturer, supplier, retailer, distributor and the customer. Entity of analysis represents the focal entity under analysis in a given research article. These entities might be either from inbound side or outbound side of SC or as a whole. The entity of analysis can be identified based on the general theme of the article apart from a cursory reading of the title, abstract, keywords and full text/body of the paper. By doing this exercise the practical aspect of the research can be recorded.

For example, the article by $\mathrm{Hu} \& \mathrm{Hsu}$ (2010) focuses on Critical factors for implementing GSCM practice in a case of electrical and electronics manufacturing industries in Taiwan. Hence, it can be easily inferred that the entity considered is the manufacturer - i.e., the electrical and electronics company. However, if there are papers, which address GSCM aspects in general irrespective of any such entities, then they are classified under "combination". Especially, those articles that deal with survey based approach, might have involved organizations that constitute different entities of SC for getting the responses and hence may not have such differentiation. For example, Cheng et al. (2008) studied the knowledge sharing among supply chain through a survey based approach in which the responses for their questionnaire are obtained from different manufacturing organizations 
falling under the different entity of analysis. Hence, it is classified under the category of "combination".

ii. Level of analysis: The SC can be analyzed at different levels. One may study the interactions between any two or more of the several entities in a SC. This classification is adopted from Croom et al. (2000), who suggested only three levels, i.e. dyadic, chain and network. A fourth level, "firm" is used by Halldorsson and Arlbjørn (2005). Hence, in this review a hybrid classification scheme suggested by Soni and Kodali (2011), which is obtained by integrating the classification schemes of Gubi et al. (2003) and Croom et al., (2000) to create four levels of analysis, is used for classification.

In an article, the author(s) would have attempted to focus on a single organization to describe a particular situation or enumerate evidence to bolster their research findings. Under such situation, the level of analysis is just carried out on a single firm. Hence such papers are categorized under a classification scheme named as "Firm". For instance, Lee T. Ru (JiunShen), Le T. P. N., Genovese A. and Koh L.S.C.(2012) discussed criteria selection of green suppliers in a hand tool industry. In this paper, the focus is merely on a single organization, whose SC was changed. Hence it is classified under "firm". On the other hand, some of the papers would discuss the interaction between any two entities of the chain and such papers would fall under "Dyad". For example, Vachon S. and Klassen R. D.(2006) discussed about the supplier customer integration in environmental monitoring. In this case, the focus of analysis is on both the supplier and customer - i.e., the interactions happening between two levels of the SC. Hence, it is classified under "Dyad". Similarly, further levels in the supply chain are "Chain" (where three or more parties are involved in the interactions) and "Network" (representingreal-life supply chains that have more than one member at the same level of the chain). Hence, papers dealing with interaction between several members in different stages of the SC were classified accordingly.

iii. Element of exchange: Croom et al. (2000) also explained that the interaction between the GSC members can be based on various factors such as exchange of asset, information, inventory, knowledge, relationship, etc. These factors are called as the element of exchange. Hence, one can also establish the taxonomy based on the element of exchange that happen between different entities under various stages of the GSC.

iv. Performance measurement: A research becomes more valuable when it reports about enhanced performance of the organization or any of the entity(s) of GSC. The importance of performance measurement is justified by Kaplan (1990).

For example, Hervani A. A., Helms M. M., and Sarkis J. (2005) find performance measures for green supply chain. This paper provides an integrative framework for study of green supply chain performance tools.

v. Areas of research / SCM issues: As mentioned earlier, the papers in the realm of GSCM deal with variety of issues. This includes strategy, logistics, performance measurement etc. which gives an idea about the focal/decision areas of GSCM. Hence, the reviewed papers were also classified according to the decision/research area.

For example, Zhu Q., Geng Y., Fujita T. and Hashimoto S.(2010) addressed the issue of "Green Supply Chain Management Implementation" by studying the case of nine large Japanese manufacturers. Hence, it is classified under the issue of "GSCM implementation" which is gaining importance in recent times in the field of SCM. 


\section{Research based classification}

This classification studies the details of the research process employed. The following are the various structural attributes under this scheme.

i. Research outlets: This gives the details of the journals, which published articles related to GSCM practices. This would help in understanding the effort of researchers and practitioners from various disciplines apart from examining the spectrum of journals that publishes papers related to GSC issues from the Indian context.

ii. Year: This gives the year in which the paper was published in the journal. The purpose of this classification is to understand growth and importance of GSCM over the years. Figure 1 shows the trend of GSCM literature that addresses the issues of GSCM for the last 16 years. It is obtained by counting the papers that are published in different journals during a given year.

\section{Take in Figure 1}

It is evident from Figure 1 that in recent times, there is an increasing interest among the researchers and practitioners in addressing the various issues of GSCM.

iii. Research design: This refers to the research instrument and methodologies used in the study (Flynn et al., 1990). One can use different methodologies such as

- Empirical

$>$ Case study

$>$ Survey

$>$ Focus group

$>$ Action research

- Desk based

$>$ Literature review

$>$ Mathematical modeling

$>$ Simulation

$>$ Experiment

The reviewed articles are organised based on the above classification mechanism. A brief about the same is presented below:

a) Methodologies used: It can be found that empirical research is highly preferred in addressing the various issue of GSC. Many papers such as Lee S.Y. (2008), Qing-hua Z. and Yi-jie D. (2007), etc. have utilised the empirical research methods such as surveys, focus groups, etc. On the other hand, the article by Chung C.J. and Weeb H.M. (2011) used a mathematical model by combining Taylor series to investigate green product designs and remanufacturing efforts. This is a perfect example of a desk based research, which involve mathematical modeling.

b) Research design: It can be seen that all forms of research design have been used in the papers reviewed. The survey method relies on self-reports of factual data, as well as opinion. One approach is to administer a survey to a group which is homogeneous with respect to at least one characteristic, such as industry or use of a common technology. For 
example, Shukla et al. (2009) conducted a survey to understand about the environmentally responsive supply chain within the Indian auto sector. They attempted to understand the practices and performance measures that can capture the environmental impact due to the GSC activities of the Indian auto sector. On the other hand, the case study documents in detail, the operations of a single plant/chain/network. This may be used in conjunction with survey research, or some other type of comprehensive data gathering effort, to develop explanations for some of the findings on a more comprehensive basis. Apart from this, there is significant number of literature reviews in the field of GSCM. Similarly, other papers that are conceptual in nature are classified accordingly.

iv. Sample industry: Supply chain research is not restricted to any particular industry. This classification is based on Burgess et al. (2006) and this criterion helps us in identifying possible sectors of GSCM research as well as highlight sectors that received inadequate attention among researchers and practitioners (Soni and Kodali, 2012).

Some papers which were based on literature review and mathematical models did not mention any particular industry. Hence, such papers are classified under a separate category called 'Not available'. For instance, the article by Ahi P. and Searcy C. (2013) reviewed the literature on definition of green and sustainable SCM and hence did not mention about any of the industries. Hence, this article is classified under the category of "Not available". On the other hand, those papers which dealt with survey collected information from multiple companies and hence they were grouped under another category called 'multiple'. Zhu Q. and Sarkis J. (2006) attempted to understand the sectoral differences in the practices of GSCM by conducting a survey, which involved companies from different industrial sectors. Hence, this paper is grouped accordingly.

\section{Results and Discussions}

Although the GSCM literature has evolved a lot in the past few decades; there are certain trends which are clearly visible. Identifying such trends and findings answers for such behaviour is referred as "synthesis" - the fourth step in the systematic approach proposed by Rousseau et al. (2008). Based on the organisation of different papers under various categories, meaningful results are synthesised. The results are presented in the same order as per the taxonomy discussed in the previous section for ease of understanding.

\section{Content based classification}

i. Entity of analysis: It can be found that there are total seven different entities. About $47 \%$ of the articles (68 out of 144) have considered combination of entities for analyzing. This shows that most of the studies too have attempted to study GSCM as a whole, rather than viewing it as individual entities. However, about $24 \%$ of the articles attempted to analyze an individual entity - namely, the manufacturer. Since, the manufacturer always play a central role in a SC, by having linkages at both upstream and downstream end, it is natural that manufacturer deserves special attention in comparison to other individual entities such as retailer (only 3 papers), supplier (only 29 papers), logistics service provider (2 papers), etc. Furthermore, the entities in downstream side of SC are not given adequate importance. 
ii. Level of analysis: Almost equal number of papers (about 39\%) are focusing at both "firm" (52 papers) as well as "chain" (57 papers), while the analysis at "dyad" level (i.e., between two stages) is least preferred - only 1 papers were found under this category. The importance towards the analysis at network and firm level may probably be due to various factors such as globalization, opening up of economy, political factors, etc. as this would affect both the individual and a network of firms. For example the case of Tata Motors is a perfect example of both firm level and network level analysis of SC. Due to political issues, the company as an individual entity was forced to shift its manufacturing location, which in turn also affected their strategic suppliers and the entire network of suppliers too moved along with Tata Motors to the new location. This example also substantiates the importance of analysis at both firm and network level.

iii. Element of exchange: It can be inferred that asset and inventory as element of exchange is less discussed in GSCM, however about 129 articles (i.e. 89\%) of articles are dealing with information exchange only. This is in line with the general theory of GSCM that information plays a vital role as an essential driver of the GSC and consequently, the "information distortion" creates major havoc within any SC. Hence, most of the researchers and practitioners too have given adequate importance to "information" as the element of exchange than inventory, assets, skills, etc.

iv. Performance measurement: It is evident that most of the articles (about 87 percent) did not focus on the performance measurement. However, this result should be inferred with adequate caution because some of the topics/issues that are addressed by the contributors may not warrant the performance measures to be studied.

v. Area of research (SCM issue): It can be found that the theme of "GSCM implementation" was frequently addressed in most of these papers. This category included articles on diverse issues such as GSCM practices, Green strategy, logistics, performance measurement, etc. These papers were classified under this category based on factors such as type of decisions addressed, profile of respondents to the survey questionnaires, time taken for implementation, etc.

\section{Research based classification}

i. Research outlets: It is evident that most of the journals are either from operations management $(\mathrm{OM})$ or from SCM. It is quite natural that authors would like to publish issues related to SC and SCM in relevant/related journals. Some of the articles surveyed got published in some journals that were not exactly related to OM/SCM but in journals related to specialised areas such as food, information technology, etc. This is primarily due to the fact, the contributors would have considered the theme of the article to be more related to other fields rather than having a direct relevance to SCM. This shows that the level of "inter-disciplinary" research is still less.

ii. Year: Based on Figure 1, it can be found that there is an increase in the number of articles over the years. However, another observation is that the trend is neither linear nor exponential and hence, it can be inferred that this growth may not be only due to the increase in number of publications every year.

iii. Research design: This categorization deals with the different types of research methods that are used by the contributors in carrying out their research. 
a) Methodologies used: About $65 \%$ of the reviewed papers utilized empirical research, while the remaining papers contributed to the desk based research. It is natural to see such importance to empirical research because the research hypotheses for various GSC issues require collecting data from multiple entities of the SC at different stages to substantiate the claims and validate them. On the other hand, if the study is carried out with respect to a single entity, using either a mathematical technique or explaining a unique situation or best practices in a case company, then desk based research could have been employed.

b) Research design: Various analysis techniques were used in the reviewed papers. Some techniques were used more than others. Generally, survey is considered to be the most commonly used research design in GSCM or management research. However, in this case, the data shows that case study still remains the most preferred choice of researchers. But a close analysis of the papers dealing with case studies revealed that usage of this method to deal at the network level is sparsely reported. Since case studies can include multiple organizations, it is surprising to note that this methodology is not being used to identify the GSCM issues in them. However, the usage of survey methods cannot be ignored as significant number of papers have also utilised this methodology. Another interesting observation is that the contributions in the form of structure or concepts are very less.

iv. Industry: The result revealed that GSC issues of diverse spectrum industries are addressed. However, as expected, most of the GSC issues are studied with respect to the manufacturing industry. About $29 \%$ of the paper dealt with manufacturing sector. It is also heartening to see that GSC issues of other sectors such as apparel, fashion and perishable food industries are also studied; the number of such studies is less than $10 \%$ of the total studies reviewed. Similarly, this also reveals that such sectors of industries are not given adequate importance in the last 15 years, as the number of publications per year is minuscule. On a positive note, this shows that these industrial segments have high potential to be researched for various SC issues.

\section{Directions for future research}

Based on this review, some directions for future research are also suggested, which are as follows:

1) It is clear that not much importance is given to understanding the interface between two or multiple stages/nodes of SC. Similarly, future research efforts should be directed towards understanding the downstream side of SC and in particular the interface between distributors and retailers, manufacturers and distributors, etc. Similarly, more studies should be directed towards understanding the role of "knowledge", "asset", "technology", etc. as an element of exchange within the GSC.

2) Another observation is that the number of papers addressing issues of Information Technology (IT) within the SCM is lesser. Hence, research focusing on such segment should be addressed in the future, as these industries in developing countries play a crucial role in shaping up the economy. 


\section{Conclusion}

This paper made an earnest attempt to provide a review of literature on GSCM. Multiple taxonomies are established to understand the contributions and efforts of the academia, researchers and practitioners and unique results and inference were made, which were detailed in the previous section. It can be concluded that with the increase in number of papers in recent years, it can be predicted that environmental issues will get more attention in the future and naturally the number of articles addressing GSC issues would also increase as the field of GSCM is evolving very fast with the changes in technology, economy and the business paradigms as a whole. One of the limitations of the existing study is that all the papers relating to this theme in the given time frame considered may not have been reviewed. This can be attributed to our selection criteria which are constrained by the limiting boundaries established as part of the systematic review process adopted. Especially, those researches that are published by Inderscience publishers, manuscripts under Open Source collections, papers published in, renowned conferences and other Indian journals are not included in the present study. Nevertheless, it is believed that this review would have provided an introductory picture towards this important research issue and our future research might delve further into this area to resolve the missing link identified in the research gap.

\section{Acknowledgement}

Author would like to thank to Er Ved Kumar Mishra (Assistant Professor and Project In-charge, Department of Biotechnology, Naraina Vidya Peeth Engineering and Management Institute (AKTU Code-429), Gangaganj, Panki, Kanpur, U.P.-India.) for supporting this work by providing a good research environment and related facilities.

\section{References}

[1] Abdallah T., Diabat A. and Rigter J. (2013) Investigating the option of installing small scale PVson facility rooftops in a green supply chain. Int. J. Production Economics

[2] Abdallah T., Farhat A., Diabat A. and Kennedy S. (2012). Green supply chains with carbon trading and environmental sourcing: Formulation and life cycle assessment. Applied Mathematical Modelling. 36, 4271-4285.

[3] Ahi P. and Searcy C.(2013). A comparative literature analysis of definitions for green and sustainable supply chain management. Journal of Cleaner Production. 52, 329-341.

[4] Al-e-hashem S.M.J. M., Baboli A. and Sazvar Z.(2013). A stochastic aggregate production planning model in a green supply chain: Considering flexible lead times, nonlinear purchase and shortage cost functions. European Journal of Operational Research. 230, $26-41$.

[5] Andic E., YurtÖ. andBaltacio glub T. (2012). Green supply chains: Efforts and potential applications for the Turkish market. Resources, Conservation and Recycling. 58, 50-68.

[6] Arimura T.H., Darnall N. and Katayama H. (2011). Is ISO 14001 a gateway to more advanced voluntary action? The case of green supply chain management. Journal of Environmental Economics and Management. 61, 170-182.

[7] Aslind N., Semana A., Zakuana N., Jusoha A., Shoki M., Arifa M. and Saman M.Z.M.(2012) The relationship of green supply chain management and green innovation concept. Social and Behavioral Sciences 57, 453-457.

[8] Bai C., Sarkis J. and Wei X.(2010). Addressing key sustainable supply chain management issues using rough set methodology. Management Research Review. 33, 1113-1127. 
[9] Barari S., Agarwal G., Zhang W.J.(Chris), Mahanty B. and Tiwari M.K.(2012). A decision framework for the analysis of green supply chain contracts: An evolutionary game approach. Expert Systems with Applications. 39, 2965-2976.

[10] Beamon B. M.(1999). Designing the green supply chain. Logistics Information Management. 12, 332-342.

[11] Bhattacharya A., Mohapatra P., Kumar V., Dey P. K., Brady M., Tiwari M.K. and Nudurupati S.S. (2013). Green supply chain performance measurement using fuzzy ANP-based balanced scorecard: a collaborative decision-making approach. Production Planning \& Control: The Management of Operations.

[12] Bjorklund M., Martinsen U. and Abrahamsson M.(2012). Performance measurements in the greening of supply chains. Supply Chain Management: An International Journal. 17, 29-39.

[13] Burgess, K., Singh, P.J. and Koroglu, R. (2006). Supply chain management: a structured literature review and implications for future research. International Journal of Operations and Production Management, 26, 703-29.

[14] Büyüközkan G. and Çifçi G. (2012) Evaluation of the green supply chain management practices: a fuzzy ANP approach. Production Planning \& Control: The Management of Operations. 23, 405-418.

[15] Cabral I., Grilo A. and Machado V.C. (2012) A decision-making model for Lean, Agile, Resilient and Green supply chain management. International Journal of Production Research 50, 48304845.

[16] Cani"els M.C.J., Gehrsitz M.H. and Semeijn J. Participation of suppliers in greening supply chains: An empirical analysis of German automotive suppliers. Journal of Purchasing \& Supply Management.

[17] Carbone V. and Moatti V. (2011) Towards greener supply chains: an institutional perspective. International Journal of Logistics Research and Applications: A Leading Journal of Supply Chain Management. 14, 179-197.

[18] Cervellon M.C. and Wernerfelt A.S.(2012). Knowledge sharing among green fashion communities online. Journal of Fashion Marketing andManagement. 16, 176-192.

[19] Chan R.Y.K., He H., Chan H.K. and Wang W.Y.C. (2012). Environmental orientation and corporate performance: The mediation mechanism of green supply chain management and moderating effect of competitive intensity. Industrial Marketing Management. 41, 621-630.

[20] Che Z.H. (2010) Using fuzzy analytic hierarchy process and particle swarm optimisation for balanced and defective supply chain problems considering WEEE/RoHS directives. International Journal of Production Research 48, 3355-3381.

[21] Chen C.C., Shih H.S., Shyur H.J. and Wu K.S.(2012). A business strategy selection of green supply chain management via an analytic network process. Computers and Mathematics with Applications. 64, 2544-2557.

[22] Chen D.J. and Liang S.W. (2012).Evaluation of Internal Costs and Benefits for Taiwanese Computer Manufacturers Adopting Green Supply Chains. The Asian Journal of Shipping and Logistics. 28, 083-104.

[23] Chen M.K., Tai T.W. and Hung T.Y.(2012). Component selection system for green supply chain Expert Systems with Applications. 39, 5687-5701.

[24] Chen Y. J. and Sheu J.B. (2009). Environmental-regulation pricing strategies for green supply chain management. Transportation Research. 45, 667-677.

[25] Cheng J.H. (2011). Inter-organizational relationships and knowledge sharing in green supply chains-Moderating by relational benefits and guanxi. Transportation Research. 47, 837-849.

[26] Cheng J.H. and Sheu J.B. (2012). Inter-organizational relationships and strategy quality in green supply chains - Moderated by opportunistic behavior and dysfunctional conflict. Industrial Marketing Management 41, 563-572. 
[27] Cheng J.H., Yeh C.H. and Tu C.W.(2008). Trust and knowledge sharing in green supply chains. Supply Chain Management: An International Journal. 13, 283-295.

[28] Chiarini A.(2013). Designing an environmental sustainable supply chain through ISO 14001 standard. Management of Environmental Quality: An International Journal 24, 16-33.

[29] Chung C.J. and Weea H.M. (2008). Green-component life-cycle value on design and reverse manufacturing in semi-closed supply chain. Int. J. Production Economics.113, 528-545.

[30] Chung C.J. and Weeb H.M. (2011). Short life-cycle deteriorating product re-manufacturing in a green supply chain inventory control system. Int. J. Production Economics 129, 195-203.

[31] Croom, S., Romano, P. and Giannakis, M. (2000). Supply chain management: an analytical framework for critical literature review. European Journal of Purchasing \& Supply Management, 6, 67-83.

[32] Cucchiella A. F., D’Adamo I., Gastaldi M.. (2011). Green Supply Chain and the Energy Recovery Plant in Social and Behavioral Sciences. 25, $54-72$.

[33] Dey P.K. and Cheffi W. (2013) Green supply chain performance measurement using the analytic hierarchy process: a comparative analysis of manufacturing organisations. Production Planning \& Control: The Management of Operations. 24, 702-720.

[34] Diabata A. and Govindanb K (2011).An analysis of the drivers affecting the implementation of green supply chain. Management. Resources, Conservation and Recycling. 55, 659-667.

[35] Elhedhli S. and Merrick R. (2012). Green supply chain network design to reduce carbon emissions. Transportation Research. 17, 370-379.

[36] Eltayeba T. K., Zailani S. and RamayahT. (2011). Green supply chain initiatives among certified companies in Malaysia and environmental sustainability: Investigating the outcomes. Resources, Conservation and Recycling. 55, 495-506.

[37] Ferretti I., Zanoni S., ZavanellaL.and Diana A. (2007). Greening the aluminium supply chain. Int. J. Production Economics. 108, 236-245.

[38] Flynn, B.B., Kakibara, S.S., Schroeder, R.G., Bates, K.A. and Flynn, E.J. (1990). Empirical research methods in operations management. Journal of Operations Management, 9, 250-84.

[39] Gavronski I., Klassen R. D., Vachon S., Felipe L. and Nascimento M. d.(2011). A resource-based view of green supply management. Transportation Research. 47, 872-885

[40] Ghosh D. and Shah J. (2012) A comparative analysis of greening policies across supply chain structures. Int. J. Production Economics. 135, 568-583.

[41] Giovanni P.D. and Vinzi V. E. (2012).Covariance versus component-based estimations of performance in green supply chain management. Int. J. Production Economics. 135, 907-916.

[42] Giunipero, L.C., Hooker, R.E., Matthews, S.C., Yoon, T.E. and Brudvig, S. (2008). A decade of SCM literature: past, present and future implications, Journal of Supply Chain Management, 44, 66-86.

[43] Green Jr K.W., Zelbst P.J., Meacham J. and Bhadauria V.S.(2012). Green supply chain management practices: impact on performance. Supply Chain Management: An International Journal. 17, 290-305.

[44] Green K., Morton B. and New S.(1998). Green purchasing and supply policies: do they improve companies' environmental performance? Supply Chain Management. 3, 89-95.

[45] Green, Jr K.W., Zelbst P. J., Bhadauria V.S. and Meacham J.(2012). Do environmental collaboration and monitoring enhance organizational performance? Industrial Management \& DataSystems. 112, 186-205.

[46] Gubi, E., Arlbjørn, J.S. and Johansen, J. (2003). Doctoral dissertations in logistics \& supply chain management. International Journal Physical Distribution \& Logistics Management, 33, 854-85.

[47] H. Kotzab, Munch H. M., Faultrier B. de and Teller C. (2011). Environmental retail supply chains: when global Goliaths become environmental Davids. International Journal of Retail \& Distribution Management. 39, 658-681. 
[48] Hall, J. (2001), "Environmental supply-chain innovation", Greener Management International. $35,105-19$.

[49] Halldorsson, A. and Arlbjorn, J.S. (2005). Research methodologies in supply chain management - what do we know? In H. Kotzab, S. Seuring, M. Muller and G. Reiner, (Eds.), Research Methodologies in Supply Chain Management (pp. 107-22). Heidelberg: Physica-Verlag.

[50] Hazen B. T., Cegielski C. and Hanna J. B. (2011). Diffusion of green supply chain management. The International Journal of Logistics Management. 22, 373-389.

[51] Hervani A. A., Helms M. M., and Sarkis J.(2005). Performance measurement for green supply chain management. Benchmarking: An International Journal. 12, 330-353.

[52] Hitchcock T.(2012). Low carbon and green supply chains: the legal drivers and commercial pressures. Supply Chain Management: An International Journal. 17, 98-101.

[53] Hoek R. I. V.(1999). From reversed logistics to green supply chains. Supply Chain Management. 4, 129-134.

[54] Holt D. and Ghobadian A. (2009). An empirical study of green supply chain management practices amongst UK manufacturers. Journal of Manufacturing Technology Management, 20, 933-956.

[55] Hsu C.C., Tan K.C., Zailani S.H.M. and Jayaraman V.(2013). Supply chain drivers that foster the development of green initiatives in an emerging economy. International Journal of Operations \&Production Management. 33, 656-688.

[56] Hsu C.W., Kuob T.C., Chenc S.H. and Hud A.H.(2011) Using DEMATEL to develop a carbon management model of supplier selection in green supply chain management. Journal of Cleaner Production 1-9.

[57] $\mathrm{Hu}, \mathrm{A} . \mathrm{H}$. and Hsu C.W. (2010). Critical factors for implementing green supply chain management practice. Management Research Review, 33, 586-608.

[58] Jaegler A. and Burlat P. (2012) Carbon friendly supply chains: a simulation study of different scenarios. Production Planning \& Control: The Management of Operations. 23, 269-278.

[59] Jamshidi R., Ghomi S.M.T.F. and Karimi B. (2012) .Multi-objective green supply chain optimization with a new hybrid memetic algorithm using the Taguchi method. ScientiaIranica $E$ 19, 1876-1886.

[60] Jensen J. K., Munksgaard K. B. and Arlbjørn J. S.(2013). Chasing value offerings through green supply chain innovation. European Business Review. 25, 124-146.

[61] Kainuma Y. and Tawara N. (2006) A multiple attribute utility theory approach to lean and green supply chain management. . Int. J. Production Economics 101, 99-108.

[62] Kannan D., Khodaverdi R., Olfat L., Jafarian A. and Diabat A. (2013). Integrated fuzzy multi criteria decision making method and multi objective programming approach for supplier selection and order allocation in a green supply chain. Journal of Cleaner Production 47, 355-367.

[63] Kaplan, R.S. (1990). Measures for Manufacturing Excellence. Boston, MA: HarvardBusinessSchool Press.

[64] Kim I. and Min H.(2011). Measuring supply chain efficiency from a green perspective Management Research Review. 34, 1169-1189.

[65] Kim J. and Rhee J. (2012) An empirical study on the impact of critical success factors on the balanced scorecard performance in Korean green supply chain management enterprises. International Journal of Production Research 50, 2465-2483.

[66] Kumar S., Teichman S. and Timpernagel T. (2012) A green supply chain is a requirement for profitability. International Journal of Production Research 50, 1278-1296.

[67] Kung F.H., Huang C.L. and Cheng C.L. Assessing the green value chain to improve environmental performance. International Journal of DevelopmentIssues. 11, 111-128.

[68] Kuo R.J., Wang Y.C. and Tien F.C. (2010). Integration of artificial neural network and MADA methods for green supplier selection. Journal of Cleaner Production. 18, 1161-1170. 
[69] Kuo T.C., Hsu C.W. , Huang S. H. and Gong D.C. (2013) Data sharing: a collaborative model for a green textile clothing supply chain. International Journal of Computer Integrated Manufacturing.

[70] Lam H. L., Ng W. P.Q., Ng R.T.L., Ng E. H., Aziz M. K. A. and Ng D.K.S.(2013) Green strategy for sustainable waste-to-energy supply chain. Energy. 1-13

[71] Larsen T. S.(2000). European logistics beyond 2000. International Journal of PhysicalDistribution \& LogisticsManagement. 30, 377-387.

[72] Lee S. M. Choi D. and Kim S. T. (2012). Green supply chain management and organizational performance. Industrial Management \& Data Systems, 112, 1148-1180.

[73] Lee S.Y.(2008). Drivers for the participation of small and medium-sized suppliers in green supply chain initiatives. Supply Chain Management: An International Journal. 13, 185-198.

[74] Lee T. Ru (Jiun-Shen), Le T. P. N., Genovese A. and Koh L.S.C.(2012) Using FAHP to determine the criteria for partner's selection within a green supply chain. Journal of Manufacturing Technology Management. 23, 25-55.

[75] Lin R.J. (2013). Using fuzzy DEMATEL to evaluate the green supply chain management practices. Journal of Cleaner Production 40, 32-39.

[76] Lina R.J., Chenb R.H. and Nguyen T.H. (2010). Green supply chain management performance in automobile manufacturing industry under uncertainty. Social and Behavioral Sciences.

[77] Mathiyazhagan K., Govindan K. and Haq A.N. (2013) Pressure analysis for green supply chain management implementation in Indian industries using analytic hierarchy process. International Journal of Production Research .

[78] Mathiyazhagan K., Govindan K., NoorulHaq A. and Y. Geng (2013). An ISM approach for the barrier analysis in implementing green supply chain management. Journal of Cleaner Production. 47 283-297

[79] McIntyre K., Smith H., Henham A. and Pretlove J.(1998). Environmental performance indicators for integrated supply chains: the case of Xerox Ltd. Supply Chain Management. 3, 149-156.

[80] McIntyre K., Smith H., Henham A. and Pretlove J.(1998). Environmental performance indicators for integrated supply chains: the case of Xerox Ltd. Supply Chain Management. 3, 149-156.

[81] Meacham J., Toms L., Jr K. W. G. and Bhadauria V. S.(2013). Impact of information sharing and green information systems. Management Research Review. 36, 478-494.

[82] Mirhedayatian S. M., Azadi M. and Saen R.F.(2013) A novel network data envelopment analysis model for evaluating green supply chain management. Int. J. Production Economics.

[83] Mishra N., Kumar V. and Chan F.T.S. (2012). A multi-agent architecture for reverse logistics in a green supply chain. International Journal of Production Research 50, 2396-2406.

[84] Mollenkopf D., Stolze H., Wendy L. T. and Ueltschy M.(2010). Green, lean, and global supply chains. International Journal of PhysicalDistribution \& Logistics Management. 40, 14-41.

[85] Muduli K., Govindan K, Barve A and Geng Y. (2013). Barriers to green supply chain management in Indian mining industries: a graph theoretic approach. Journal of Cleaner Production. 47 335-344.

[86] Mudulia K., Govindan K., Barvea A., Kannan D. and Geng Y. (2013). Role of behavioural factors in green supply chain management implementation in Indian mining industries. Resources, Conservation and Recycling 76, 50-60.

[87] Murray J. G.(2000). Effects of a green purchasing strategy: the case of Belfast City Council. Supply Chain Management: An International Journal. 5, 37- 44.

[88] Naini S.G.J., Aliahmadi A. R. and Eskandari M. J. (2011).Designing a mixed performance measurement system for environmental supply chain management using evolutionary game theory and balanced scorecard: A case study of an auto industry supply chain. Resources, Conservation and Recycling. 55, 593-603. 
[89] Olugu E. U., Wong K. Y. and Shaharoun A. M. (2011). Development of key performance measures for the automobile green supply chain. Resources, Conservation and Recycling. 55, $567-579$.

[90] Ondemir O. (2012) Green Supply Chain Management: Product Life Cycle Approach. International Journal of Production Research 50, 5669-5670.

[91] P. Hong, H.B. Kwon and Roh J. J.(2009). Implementation of strategic green orientation in supply chain. European Journal of InnovationManagement. 12, 512-532.

[92] Paksoy T., Bektasb T. and Ozceylan E. (2011). Operational and environmental performance measures in a multi-product closed-loop supply chain. Transportation Research. 47, 532-546.

[93] Paksoy T., Pehlivan N.Y. and Özceylan E. (2012) Fuzzy Multi-Objective Optimization of a Green Supply Chain Network with Risk Management that Includes Environmental Hazards. Human and Ecological Risk Assessment: An International Journal 18, 1120-1151.

[94] Perotti S., Zorzini M., Cagno E. and Micheli G.J.L.(2012).Green supply chain practices and company performance: the case of 3PLs in Italy. International Journal of PhysicalDistribution \& Logistics Management. 42, 640-672.

[95] Qing-hua Z. and Yi-jie D. (2007). Evolutionary Game Model between Governments and Core Enterprises in Greening Supply Chains. Systems Engineering - Theory \& Practice. 27, 85-89.

[96] Rao P. and Holt D. (2005). Do green supply chains lead to competitiveness and economic performance? International Journal of Operations \& Production Management. 25, 898-916.

[97] Rao P.(2002). Greening the supply chain: a new initiative in south East Asia. International Journal Of Operations \& Production Management. 22, 632-655.

[98] Saadany A.M.A. El, Jaber M.Y. and Bonney M.(2011). Environmental performance measures for supply chains. Management Research Review. 34, 1202-1221.

[99] Sachan, A. and Datta, S. (2005). Review of supply chain management and logistics research. International Journal Physical Distribution \& Logistics Management, 35, 664-704.

[100] Sarkis J.(2003). A strategic decision framework for green supply chain management Journal of Cleaner Production. 11, 397-409.

[101] Sarkis J.(2012). A boundaries and flows perspective of green supply chain management. Supply Chain Management: An International Journal. 17, 202-216.

[102] Sarkis J., Zhu Q. and HungLai K.(2011). An organizational theoretic review of green supply chain Management literature. Int. J. Production Economics 130, 1-15.

[103] Sarkis, J. (2001), "Manufacturing's role in corporate environmental sustainability: concerns for the new millennium", International Journal of Operations \& Production Management. 21, 66685.

[104] Sarkis, J. (2003), "A strategic decision making framework for green supply chain management", Journal of Cleaner Production, 11, 397-409.

[105] Sarmiento R. and Thomas A.(2010). Identifying improvement areas when implementing green initiatives using a multitier AHP approach. Benchmarking: An International Journal.17, 452-463.

[106] Shang K.C., Lu C.S. and Li S. (2010). A taxonomy of green supply chain management capability among electronics-related manufacturing firms in Taiwan. Journal of Environmental Management. 91, 1218-1226.

[107] Sharma A., krishnan G. and Iyer R. (2012) Resource-constrained product development: Implications for green marketing and green supply chains. Industrial Marketing Management 41, 599-608.

[108] Shaw S. and Grant D. B. and Mangan J.(2010). Developing environmental supply chain performance measures. Benchmarking: An International Journal.17, 320-339.

[109] Shenc L., Olfat L., Govindanb K., Khodaverdia R., and Diabatd A. (2013).A fuzzy multi criteria approach for evaluating green supplier's performance in green supply chain with linguistic preferences. Resources, Conservation and Recycling. 74, 170- 179. 
[110] Sheu J.B. (2008). Green supply chain management, reverse logistics and nuclear power generation. Transportation Research. 44, 19-46.

[111] Sheu J.B. (2011). Bargaining framework for competitive green supply chains under governmental financial intervention. Transportation Research. 47, 573-592

[112] Sheu J.B. and Chen Y. J. (2012). Impact of government financial intervention on competition among green supply chains. Int. J. Production Economics .138, 201-213.

[113] Sheu J.B., Chou Y.H. and Hu C.C.(2005). An integrated logistics operational model for greensupply chain management. Transportation Research. 41 287-313.

[114] Shi V. G., Koh S.C. L. Baldwin J and Cucchiella F.(2012). Natural resource based green supply chain management. Supply Chain Management: An International Journal. 17, 54-67.

[115] Shukla A. C., Deshmukh S.G. and Kanda A. (2009). Environmentally responsive supply chains. Journal of Advances in Management Research. 6, 154-171.

[116] Shukla A. C., Deshmukh S.G. and Kanda A. (2009). Environmentally responsive supply chains. Journal of Advances in Management Research. 6, 154-171.

[117] Simpson, D., Power, D. and Samson D. (2007). Greening the automotive supply chain: a relationship perspective. International Journal of Operations \& Production Management, 27, 28 48.

[118] Soni, G. and Kodali, R. (2011). A critical analysis of supply chain management content in empirical research. Business Process Management Journal, 17, 238-266.

[119] Soni, G. and Kodali, R. (2012). A critical review of empirical research methodology in supply chain management. Journal of Manufacturing Technology Management, 23, 753-779.

[120] Srivastava S.K. (2007). Green supply chain management: a state of art literature review. International Journal of Management Reviews 9, 53-80.

[121] Styles D., Schoenberger H and Galvez-Martos J.L. (2012).Environmental improvement of product supply chains: Proposed best practice techniques, quantitative indicators and benchmarks of excellence for retailers. Journal of Environmental Management. 110, 135-150.

[122] Styles D., Schoenberger H. and Galvez-Martos J.L. (2012). Environmental improvement of product supply chains: A review of European retailers' performance. Resources, Conservation and Recycling. 65, 57- 78 .

[123] Sundarakani B., DeSouza R., Goh M., Wagner S.M. and Manikandan S. (2010) Modeling carbon foot prints across the supply chain. Int. J. Production Economics. 128, 43-50.

[124] Swami S. and Shah J.(2013). Channel coordination in green supply chain Management. Journal of the Operational Research Society. 64, 336-351.

[125] Testa F. and Iraldo F. (2010). Shadows and lights of GSCM (Green Supply Chain Management): determinants and effects of these practices based on a multi-national study. Journal of Cleaner Production. 18, 953-962.

[126] Tsai W.H. and Hung S.J. (2009) A fuzzy goal programming approach for green supply chain optimisation under activity-based costing and performance evaluation with a value-chain structure. International Journal of Production Research 47, 4991-5017.

[127] Tseng M.L. (2011). Green supply chain management with linguistic preferences and incomplete information. Applied Soft Computing. 11, 4894-4903.

[128] Tseng M.L. and Chiu A.S.F. (2013). Evaluating firm's green supply chain management in linguistic preferences. Journal of Cleaner Production. 40, 22-31.

[129] Tseng M.L., Tan K.H., Lim M., Lin R.J. and Geng Y. (2013) Benchmarking eco-efficiency in green supply chain practices in uncertainty. Production Planning \& Control: The Management of Operations.

[130] Vachon S. (2007) Green supply chain practices and the selection of environmental technologies. International Journal of Production Research 45, 4357-4379.

[131] Vachon S. and Klassen R. D.(2006). Extending green practices across the supply chain. International Journal of Operations \&Production Management. 26, 795-821. 
[132] Walkera H., Sistob L.D. and Bainc D. M. (2008). Drivers and barriers to environmental supply chain management practices: Lessons from the public and private sectors. Journal of Purchasing \& Supply Management. 14, 69-85.

[133] Wang F., Lai X., and Shi N.(2011). A multi-objective optimization for green supply chain network design. Decision Support Systems. 51, 262-269.

[134] Wang X. and Chan H. K. (2013) A hierarchical fuzzy TOPSIS approach to assess improvement areas when implementing green supply chain initiatives. International Journal of Production Research 51, 3117-3130.

[135] Wanga X., Chan H.K., Yee R.W.Y. and Rainey I.D.(2012) A two-stage fuzzy-AHP model for risk assessment of implementing green initiatives in the fashion supply chain. Int. J. Production Economics 135, 595-606.

[136] Wanga Y.F., Chenb S.P., Leea Y.C. and Tsaia C.T. (Simon).(2013).Developing green management standards for restaurants: An application of green supply chain management. International Journal of Hospitality Management. 34, 263- 273.

[137] Wua K.J., Tseng M.L. and Vy T. (2011). Evaluation the drivers of green supply chain management practices in uncertainty. Social and Behavioral Sciences. 25, $384-397$.

[138] Xie Y. and Breen L.(2012). Greening community pharmaceutical supply chain in UK: a cross boundary approach Supply Chain Management: An International Journal. 17, 40-53.

[139] Yang C.S., Lu C.S., Haider J.J. and Marlow P.B. (2013) The effect of green supply chain management on green performance and firm competitiveness in the context of container shipping in Taiwan. Transportation Research 55, 55-73.

[140] Yeh W.C. and Chuang M.C. (2011). Using multi-objective genetic algorithm for partner selection in green supply chain problems. Expert Systems with Applications 38, 4244-4253.

[141] Yinga J. and Li-junb Z. (2012). Study on Green Supply Chain Management Based on Circular Economy. Physics Procedia 25, 1682 - 1688.

[142] Youn S., Yang M. G. (Mark) and Roh J. J.(2012). Extending the efficient and responsive supply chains framework to the green context. Benchmarking: An InternationalJournal. 19, 463-480.

[143] Zhang C.T. and Liu L.P. (2013) Research on coordination mechanism in three-level green supply chain under non-cooperative game. Applied Mathematical Modeling 37, 3369-3379.

[144] Zhao R., Neighbour G., Han J., McGuire M. and Deutz P. (2012). Using game theory to describe strategy selection for environmental risk and carbon emissions reduction in the green supply chain. Journal of Loss Prevention in the Process Industries 25, 927-936.

[145] Zhu Q. and Cote R.P. (2004). Integrating green supply chain management into an embryonic ecoindustrial development: a case study of the Guitang Group. Journal of Cleaner Production. 12, $1025-1035$.

[146] Zhu Q. and Sarkis J. (2004) Relationships between operational practices and performance among early adopters of green supply chain management practices in Chinese manufacturing enterprises. Journal of Operations Management 22, 265-289.

[147] Zhu Q. and Sarkis J. (2007) The moderating effects of institutional pressures on emergent green supply chain practices and performance. International Journal of Production Research 45, 43334355.

[148] Zhu Q. and Sarkis J.(2006). An inter-sectoral comparison of green supply chain management in China: Drivers and practices. Journal of Cleaner Production. 14 472-486.

[149] Zhu Q., Geng Y., Fujita T. and Hashimoto S.(2010). Green supply chain management in leading manufacturers. Management Research Review. 33, 380-392.

[150] Zhu Q., Geng Y., Sarkis J. and Lai K.H. (2011). Evaluating green supply chain management among Chinese manufacturers from the ecological modernization perspective. Transportation Research. 47, 808-821. 
[151] Zhu Q., J. Sarkis and Geng Y. (2005). Green supply chain management in China: pressures, practices and performance. International Journal of Operations \& Production Management. 25, 449-468.

[152] Zhu Q., Sarkis J. and Lai K. (2007).Green supply chain management: pressures, practices and performance within the Chinese automobile industry. Journal of Cleaner Production. 15, 10411052.

[153] Zhu Q., Sarkis J. and Lai K. (2008). Green supply chain management implications for "closing the loop'. Transportation Research. 44, 1-18.

[154] Zhu Q., Sarkis J. and Lai K. (2012) Green supply chain management innovation diffusion and its relationship to organizational improvement: An ecological modernization perspective. J. Eng. Technol. Manage. 29, 168-185.

[155] Zhu Q., Sarkis J. and Lai K. Institutional-based antecedents and performance outcomes of internal and external green supply chain management practices. Journal of Purchasing \& Supply Management

[156] Zhu Q., Sarkis J. and Lai K.(2007). Initiatives and outcomes of green supply chain management implementation by Chinese manufacturers. Journal of Environmental Management. 85, 179-189.

[157] Zhu Q., Sarkis J. and Lai K.H. (2012) Examining the effects of green supply chain management practices and their mediations on performance improvements. International Journal of Production Research 50, 1377-1394.

[158] Zhu Q., Tian Y. and Sarkis J. (2012) Diffusion of selected green supply chain management practices: an assessment of Chinese enterprises. Production Planning \& Control: The Management of Operations. 23, 837-850.

[159] Zhu, Q. and Sarkis, J. (2004). Relationships between operational practices and performance among early adopters of green supply chain management practices in Chinese manufacturing enterprises. Journal of Operations Management, 22, 265-289.

[160] Zhua Q., Sarkis J. and Lai K.H.(2008). Confirmation of a measurement model for green supply chain management practices implementation. Int. J. Production Economics. 111, 261-273.

[161] Zhua Q., Sarkis J., Cordeiroc J. J. and Lai K.H. (2008). Firm-level correlates of emergent green supply chain management practices in the Chinese context. Omega. 36, 577 - 591.

\footnotetext{
*Corresponding author.

E-mail address: pratiksha.mnit@gmail.com
} 